\title{
Conservation of monasteries by adaptive reuse: the added value of typology and morphology
}

\author{
K. Lens ${ }^{1,2}$, B. Plevoets ${ }^{1,2}$ \& K. Van Cleempoel ${ }^{1,2}$ \\ ${ }^{1}$ Faculty of Architecture and Art, Hasselt University, Belgium \\ ${ }^{2}$ Hasselt PHL, Belgium
}

\begin{abstract}
Over the past 1,400 years, religious Christian churches and monasteries have marked the landscape and social life of Europe. Yet the on-going process of secularisation affects our religious heritage: it becomes underused or even abandoned. Our research focuses on the potential role of the architectural discipline in the discourse of reusing monasteries; research by design is implemented as an exploration tool, starting from a large survey of subtypologies of Christian monasteries in Western Europe.

This paper presents the first phase of our project: a survey of Christian monasteries in a specific study area (the Belgian province Limburg), and their analysis and classification into sub-typologies. Important sources are historical and architectural literature, but also local archives, databases, site visits, and newspapers. The inventoried sub-typologies are translated through sketches and schemes into models, which facilitate analysis of and communication about the existing monastic buildings. Practising adaptive reuse, the choice of an appropriate new program to a structure is vitally important to reinforce the original building character. The paper concludes by indicating the most suitable models to be implemented by social important (ambivalent) care programs through research by design, in hybrid combinations with other functions.

Keywords: monastery, adaptive reuse, (sub-)typologies, models, (ambivalent) care programs, research by design.
\end{abstract}

\section{Introduction}

Adaptive reuse has proven to be an important strategy in conserving historical buildings [1] but the question for adaptation and reuse becomes more delicate 
when it comes to religious heritage buildings, such as churches and monasteries. Most of the Belgian catholic houses of worship are community property since French Revolution. As the maintenance, conservation and restoration of these buildings is expensive, communities do not want churches to fall into abeyance caused by secularisation. Therefore Flemish administration and ecclesiastical government are working on a short- and long-term vision for the future [2, 3].

Although the occupancy of monastic buildings diminishes due to the same social evolution, monasteries rather go unremarked in this discussion of civil and church administrations since they are private property and no responsibility of the Episcopal Diocese. As the problems for this typology is less sticking, there is limited scholarly research on adaptive reuse of monasteries. But still these buildings face the same challenges due to secularisation. The mentioned confiscation of church properties around 1789 even caused the closing of large numbers of these premises. After a strong growth of new congregations between 1830 and 1950, the Second Vatican Council (1962-1965) triggered more openness both literally and figuratively speaking. But this wind of change could not stop the secularization, so monasteries depopulated systematically.

At the same time, monasteries are particularly interesting for reuse due to their location, history and 'flexible' typology. Monastic sites are usually situated on picturesque and important locations in city centres or rural areas, which makes them attractive for reuse. Repeatedly abbots and abbesses modified them for religious, organizational and other reasons, including a change of architectural styles. As a result of these adaptations, various monastic buildings were subject of internal adaptive reuse. Nowadays, however, even when there are immediate heirs, like hospitals and schools connected to convents, there seems to be a lack for a long-term vision of their potential in the urban fabric.

Social, economical and cultural interests emphases the importance to act prudently. The increasing demand for (ambivalent) care programs due to recent demographic evolutions, may present a practical opportunity reprogramming vacant or underused monasteries. The exact programme, however, depends on the sub-typology: a countryside abbey, a city centre refuge, a 19th century convent with long passages, a nunnery in a villa, etc. It is evident that each typology carries different potentials. A detailed inventory may provide more insight in the sub-typology of the monasteries in our study-area and as such their reuse-potential [4].

Our research focuses on the potential role of the architectural discipline in the discourse of reusing monasteries: research by design is implemented as an exploration tool, starting from a large survey of sub-typologies of Christian monasteries in Western Europe. This paper presents the first phase of our project: a survey of Christian monasteries in the form of an inventory of a specific study area - the Belgian province Limburg - and their analysis and classification into sub-typologies. In a next step, the inventoried sub-typologies are translated through sketches and schemes into models, which facilitate analysis of and communication about the existing monastic buildings. 


\section{Defining the typology of the Christian Monastery in Western Europe}

A first step and method is defining the typology of the Christian monastery. Leading writers about architectural history of religious and other buildings, focus particularly on churches. Pevsner [6] and Norberg-Schulz [7] refer, although briefly, to the 'perfect' but never built abbey of Saint-Gallen, probably designed by abbot Gozebert in 830. Other France monastic buildings mentioned in architectural overviews are the 12th century destroyed abbey of Cluny and the monastery of Sainte Marie de la Tourette (1954-1957) by Le Corbusier, which despite belonging to different periods show important similarities [8].

History books concerning western European monasteries give a sense of turbulent beginnings and evolutions of monasteries. In the introduction to his overview, Krüger and Toman [9] describe a monastic life as an alternative for a life within society, and as such the monastery as a building typology facilitated this 'solitary living'. Paradoxically, in spite of being isolated from society, the monastic live has always influenced society. Regarding his work and the analyses of Lawrence [10], all adaptations to monastic life and buildings are a result of interactions between the monastery and the outside.

The word 'monastery' also finds its origin in this idea. The term 'monk' is a derivative of the Greek word 'monos', which means alone. Monks live a life of solitude and asceticism in search of spirituality. Initially these 'monks' lived separated as a hermit in the desert, but soon they start to live in small groups in a 'laura', a group of cells on one dessert site. The Greek words 'koinos' (together) and 'bios' (life) merged into the term 'coenobium' or cenobitic. When a cenobitic community became too large for solitary living, the community was split up and a new group was founded with a new leader.

In the course of history, the typology of the monastery evaluated and developed further based on monastic rules. As a general characteristic, in different times and constellations, monastery walls surrounded a group of buildings such as church or chapel, refectory, kitchen, cells with an oratorium or prayer area, infirmary, comfortable guest house, library, scriptorium, service buildings, alms house, etc. As a result, monasteries represent a very diverse typology which may be subdivided in different 'sub-typologies' among which a countryside abbey, a city centre refuge, a $19^{\text {th }}$ century convent with long passages, a nunnery in a villa.

\section{Making an inventory of monasteries in Limburg, Belgium}

\subsection{Methodology}

Monastic buildings are coming onto the real estate market in high speed, often without much publicity. To gain a clear insight into objective and quantitative data of existing monasteries - such as amount, location, size, organization -, an inventory of this typology in a specific study area, the Belgian Province Limburg, is conducted. 
Inventories in the cultural heritage sector have proven to be an important instrument which allows us to control, manage, and unlock information on a specific subject or typology [11, 12]. Moreover, Fuentes [4] has described how an inventory may also be used to investigate the reuse potential of a specific architectural typology. The main objective of our inventory is to identify the existing monasteries in the study area and to locate them geographically. In addition, basic data about the building, such as name(s), ownership, and building's history is added in the form of a building record card. The record cards are properly designed to improve the collection of data, possibly also by students or public servants, and to allow a comparative analysis.

The inventory is nourished through fieldwork and documentary sources. Documentary sources - among which local archives of municipalities or Public Welfare Centres, databases, literature and newspapers - are helpful to minimize fieldwork, which is rather time-consuming due to a large number of constructions to be considered.

\subsection{Record card as building block}

The record card is the basis for collecting and managing research data to be included in the inventory. As such, these cards are the 'building blocks' for our inventory. The card includes seven sections:

1. Geography;

2. Monastery name(s);

3. Administrative data;

4. Visual data on the defacto situation;

5. Building data;

6. Former and actual use;

7. Sacred place.

In what follows, we discuss more in depth the different aspects considered in each of these sections. A set of key words are defined in order to simplify the consultation of the inventory.

The inventoried monasteries are included in a geo-portal based on a Geographic information system (GIS). GIS is also used by the Flemish Government to unlock information to the public about cultural estate heritage (fig. 1).

\subsubsection{Geography}

Primarily the monasteries are ranked by location. Pointed out on a map with municipality bounderies, centra, rouds, rivers, ... different aspects of a monastery could be visualised effectively using different layers for various information of the nearness of one or more monasteries influences the possibilities for reuse. 


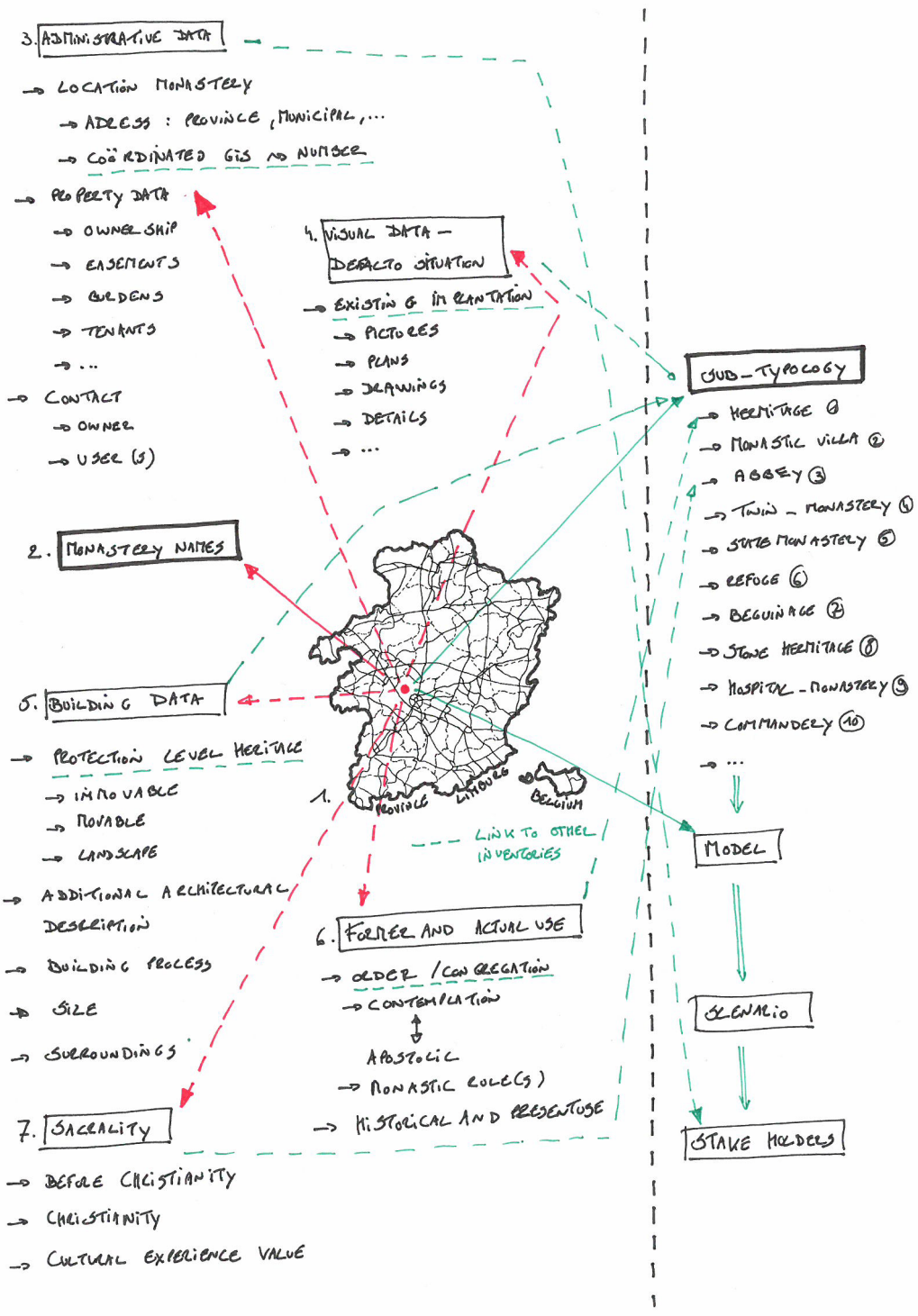

Figure 1: Inventory with frame filling cards (using geoportal based GIS) toward sub-typologies and models.

\subsubsection{Monastery name(s)}

In many cases a monastic site is known by different names. Those appellations are often references to different characteristics of this buildings such as location, physical eye-catcher, functions or uses, previous or current inhabitants, the 
colour of the monks or nuns habits. First the official name is mentioned, followed by occasional nicknames.

\subsubsection{Administrative data}

This practical section catalogues detailled information about the location of a monastery, but also upon ownership, easement, burdens to the estate or tenants. Furthermore it gives information on present owners and users.

\subsubsection{Visual data on the defacto situation}

This section includes pictures, drawings, plans, details, building models, etc. of the existing situation. The position from where photographs or sketches were made, are visualized on a site plan. Whenever possible, we will make use of existing inventories by putting up links.

\subsubsection{Building data}

Several monasteries are officially recognized as cultural and historical important movable and immovable heritage, including gardens and landscapes. Depending on the type of protection of the building or its furniture, different types of intervention to the building will be allowed. Sometimes this protection only is valid to some parts of an estate and its accommodation.

Protected monasteries have been included in inventories of the regional government, or research centres like the Centre for Religious Art and Culture (CRKC). This section will look for possible links to these existing lists with building data, architectural styles, original programmes and functions. But not every monastic building is protected heritage and only historical buildings are admitted to this inventory. As our inventory aims to gather information about all monasteries in Limburg, field work needs to be conducted to fill in missing data.

Furthermore this section gives the size of the monastic building parts and grounds in order to give a hint of the scale, concluding with data about the architectural en scenic surroundings. Johannes Cramer and Stefan Breitling reinforce in their study about architecture in existing fabric the importance of the existing an historical urban tissue [13].

\subsubsection{Former and actual use}

The way of life of the founders of a monastery determinded to a large extent also the architecture of the building. A important difference extists between orders and congregations. An order is founded before 1550 and is mostly situated in a rural abbey and rather closed and autonomous, while a congregetion is younger than 1550, located both in the country or city and more open to its surroundings by organizing a hospital, school, etc. A contemplative order or congregation is a closed community while a apostolic monastic group moves into the world. Their respective used buildings and location are a direct result. Most frequently orders are contemplative and congregations more apostolic.

The presence of monks or nuns will have an influence on the possibilities towards adaptive reuse. These religious habitants sometimes want to participate in or even slow down the adaptation process. At the same time an integrating vision will aim for a flexible, rich and hybrid solution. Partial secularisation of a 
religious site can work. The abbey of Herkenrode, Hasselt in Belgium is a good example of this theory. Furthermore other religious or non-religious former and present use are modifying future adaptive reuse of monasteries themselves or neighbouring monastic buildings. The connection to the property of schools or hospitals is decisive. Also the past deconstruction of parts or full structure and external existing plans for the future will be reported.

The succession of different orders or congregations concerns other accents depending on the use of different monastic rules.

\subsubsection{Sacred place?}

Whit in the section 'sacred place' we distinguish two types of sacredness. The first type is the so-called 'intrinsic sacral aspect of a place'. Next to the architectural or residential history and the pragmatic attitude of habitants and administrations, the sacral past of a monastery is an important factor to assess the distinctive values of a monastery. Sometimes one can find echo's of the German and Roman or even older rituals on the spot of a present religious building. Often the young Christian church tried to assimilate the old habits and locations to legitimatize its own way of life. Also during different mission waves in Western Europa, martyrs and new saints were very appealing to Christian believers. Sometimes the sacredness of a site was defined by historical events or even stories, but the presence of relics of holy people who lived in faraway places could be enough to found or to substantiate new religious or general communities

The second type of sacredness is less site-specific and is more applicable to religious buildings in general. Given the accelerated secularisation several authors like Rajesh Heynickx, Thomas Coomans, Herman De Dijn, Jan De Mayer, Bart Verschaffel and Marc Dubois put forward their distinctive views on 'loci sacri' and abandoned religious places $[14,15]$. Most of them are very cautious but supportive towards adaptive reuse of religious buildings due to the immaterial sacral atmosphere of the building. Yet, Jacques De Visscher suggests demolishing empty churches and monasteries rather making them a subject of adaptive reuse.

On the contrary, Graeme Brooker, when he speaks about contaminated buildings, appreciates the opportunities laying in the complexity of remodelling these types of 'meaning-loaded' or 'contaminated' buildings. The contamination gives an added value to both the properties and the adaptive reuse [16]. Ellen Klingenberg takes this further and presumes a 'cultural experience value' to interiors like monasteries [17].

\section{Towards sub-typologies and models}

\subsection{Subtypologies: possible distinction}

Monastic facilities are very diverse in shape, arrangement, building history and surroundings. Therefore the typology 'monastery' can be subdivided in different sub-typologies. This sub-division makes it possible to point out some important characteristics of this type of religious buildings and its (former) inhabitants. 
One key feature stands out: independent of age, location or building style, a monastery is directly shaped through the monastic rule(s) used by the founding monks or nuns. Not only these rules form an occurring theme in works of Lawrence [10] and Krüger and Toman [9] above mentioned, also Alexander Bales putted forward the idea of a strong relationship between a monastic building and use [18]. The latter made a study about the Carthusian monastery of Maria e San Giovanni Battista. Doing a parallel reading of the Order's founding rules and of self made plans or sketches of the monastic building, he noticed the Carthusian's constancy of religious values and ideals produced a distinct type of monastery in which site, symbolism, ritual and architecture are layered and interwoven.

The first to determine guidelines for an ascetic life were the Desert Fathers and their followers. But the standard towards a cenobitic monasticism was the rule of Saint-Benedict of Nursia at the end of the $6^{\text {th }}$ century. His vision corresponded to the reality of his time. Next movements in monastic life like Cluny, Cistercians, knight-monks, Saint-Francis and mendicant friars and beguinages were almost always a reinstallation of or reaction to this rule.

One can read the evolution of monastic thinking in the evolution of the architecture of monastic sub-typologies and of the use of basic elements of a monastery in specific sub-typologies. Hermitage, monastic villa, abbey, twinmonastery, state-monastery, refuge, beguinage, stone hermitage, hospitalmonastery, commandery, etc. are expressions of different views on a monastic community in time, surroundings and society.

Even today monasteries are built or rebuilt using monastic rules from SaintBenedict or others like Saint-August. A recent example is the adaptations of 2012 to a monastery of Saint-August in Bouge near to Namen in Belgium [19].

\subsection{The importance of models}

The mentioned plan of Saint-Gallen is called an ideal translation of the rule of Saint-Benedict (fig. 2A). Therefore it is a clear example of the sub-typology abbey. When we compare this drawing to schema's of an abbey from Limburg, e g. Colen, we see an interpretation of the sub-typology (fig. 2B). The cloister is the central part of a much smaller monastery. The church is linked in a similar way to the church, but the buildings containing guests, work staff, crafts and cattle are organised in a different and more concentrated way.

Meanwhile it is possible to make the same connection between to monasteries with a different sub-typology. A commandery like Alden-Biesen is also a monastic estate based to the Benedictine rule but has its own characteristics because of its military purposes (fig. 2C). Yet an urban beguinage like Tongeren is very different from start to setting towards a rural abbey. But the monastic dwellings are situated in a similar manner around the church (fig. 2D).

Using the record cards, results of fieldwork and documentary sources - to compare the different sub-typologies in existing situations, allows us to define models what can be used to communicate to stakeholders involved in the reuse of monasteries. 


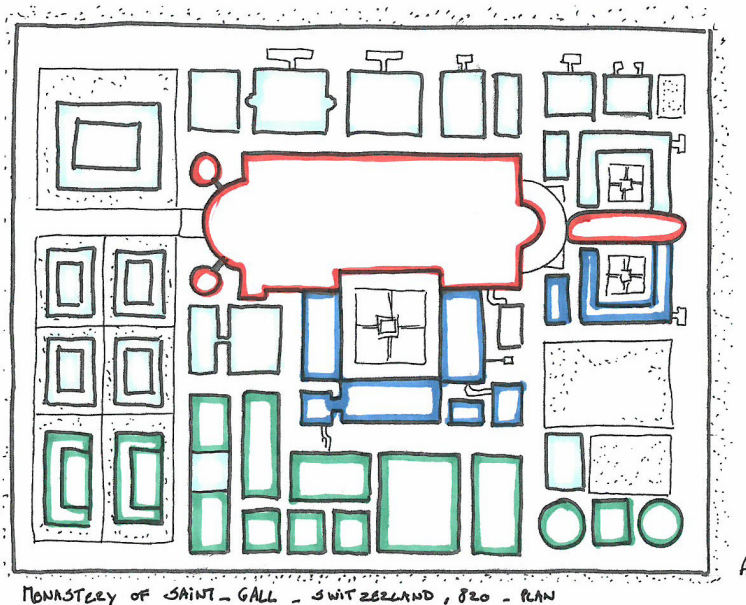

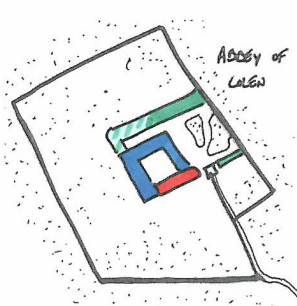

B.

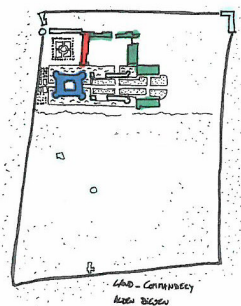

C.

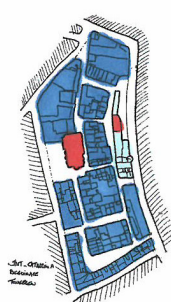

$\triangle$.

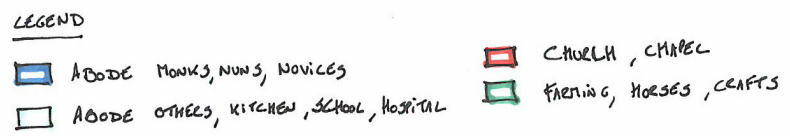

Figure 2: $\quad$ Schemes of sub-typologies abbey, commandery and beguinage.

\section{Conclusion/discussion}

In order to survive the threats caused by the on-going secularisation process, monasteries need to be adapted to find a new use. Fred Scott describes this difficult paradox between the transformation of an existing building to protect it from disappearing on the one hand, and saving the original function at all costs to keep the significance of an estate at the other hand [20]. As such, adaptive reuse is to complex and has too much potential to let it depend on coincidence commitment of some stakeholders [21]. Some administrations, like the Dutch and Portuguese for instance, stimulate the reprogramming of monasteries to specific directions like care and hotels [22]. But architectural, social, economical and cultural interests ask for more scientific based decisions.

We may well consider the memories of monasteries as a source of inspiration for reprogramming them. Their social role in local communities is, for example, 
inspiring. Ambivalent care could be the spearhead of this policy. Using the inventory based models to check which sub-typologies of monastic buildings are suitable to serve this purpose, will be the next step of this research without freezing a hybrid and flexible compilation of functions (fig. 1).

\section{Acknowledgement}

The research of Bie Plevoets was funded by a $\mathrm{PhD}$ grant from the Institute for the Promotion of Innovation through Science and Technology in Flanders (IWTVlaanderen).

\section{References}

[1] Plevoets, B., and Van Cleempoel, K. (2013). Adaptive reuse as an emerging discipline: an historic survey. In G. Cairns (Ed.), Reinventing Architecture and Interiors - the past, the present and the future. London: Libri Publishers.

[2] Voorzitters van de werkgroepen 'bestuurskracht en financiering', 'beheer', en '(her)bestemming en ruimtelijke inpassing van parochiekerken, (2011). Verslag: Parochiekerken in Vlaanderen: Bestuurskracht en financiering, beheer, (her)bestemming en ruimtelijke inpassing. Brussel: Agentschap voor Binnenlandsbestuur.

[3] Vlaamse Overheid, Agentschap R-O Vlaanderen, and Onroerend Erfgoed (Eds.), (2009). In een ander licht. Herbestemming van religieus erfgoed. Brussel: Luc Tack.

[4] Fuentes, J. M. (2010). Methodological bases for documenting and reusing vernacular farm architecture. Journal of Cultural Heritage 11, 119-129.

[5] Cramer, J., and Breitling, S. (2007). Architecture in existing fabric. Berlin: Birkhäuser.

[6] Pevsner, N. (1977). An outline of European architecture. Harmondsworth: Penguin.

[7] Norberg-Schulz, C. (1980). Meaning in Western Architecture. London: Studie Vista.

[8] Klinkhammer, B. (2011). Ineffable space: Le Corbusier's colour schemes for the Monastery Sainte Marie de la Tourette. Paper presented at the Structural Repairs and Maintenance of Heritage Architecture XII, Chianciano Terme, Italy.

[9] Krüger, K., Toman, R., e.a. (vertaling door van der Kooij, A., Post, E., e.a. van 'Orden und Klöster - 2000 Jahre christliche Kunst und Kultur, 2008). Kloosters en Kloosterorden: 2000 jaar christelijke kunst en cultuur. Groningen, Persklaar.

[10] Lawrence, C.H. (vertaling door Ad Rem Tekst, E. Franemölle van 'Medieval Monasticism - Forms of religious life in Western Europe in the middle ages, $3^{\text {rd }}$ Edition 2001 (1984). Inhoudelijke beoordeling en auteur van Hoofdstuk 15, Kloosterleven in de Lage Landen, door P. De Grieck, 
2004). Kloosterleven in de Middeleeuwen: in West-Europa en de Lage Landen. Amsterdam: Pearson Education Benelux.

[11] Van Aerschot-Van Haeverbeeck, S., Inventarisatie van het bouwkundig erfgoed: een eindeloos verhaal, Monumenten en Landschappen 22, 1 (2003).

[12] Van Dyck, A. (2013), Religieus erfgoed inventariseren: Hoe en waarom. Paper presented at Religieus cultureel erfgoed in Haspengouw in beweging, Bilzen, Belgium.

[13] Cramer, J., and Breitling, S. (2007). Architecture in existing fabric. Berlin: Birkhäuser.

[14] Coomans, T., De Dijn, H., De Maeyer, J., Heynickx, R., and Verschaffel, B. (Eds.). (2012). Loci Sacri. Understanding Sacred Places. Leuven: Leuven University Press.

[15] Dubois, M., Coomans, T., e.a. Wat Aanvangen Met 'Gewijde Gebouwen’?, Kunsttijdschrift Vlaanderen 52, no. 5 (2003): 265-300.

[16] Brooker, G. (2009). Infected Interiors: Remodelling Contaminated Buildings. Paper presented at the Living in the Past: Histories, Heritage and the Interior. 6th Modern Interiors Research Centre Conference, 14 and 15 May. London: Kingston University London.

[17] Klingenberg. E. (2012), Conservation of cultural memories in interiors: a challenge for new use. Paper presented at the IE International Conference 2012. Reinventing Architecture and Interiors: the past, the present and the future, Ravensbourne, U.K.

[18] Bales, A., Mapping rituals in a Carthusian Monastery: La Certosa di Calci, Journal of Architectural Education 54, no. 4 (2001), 264-267.

[19] Chabard, P., Ascese, A+ 239 (2013): 48-49.

[20] Scott, F. (2008). On Altering Architecture. London: Routledge.

[21] Wijnekus, J. (2009), Herbestemming van Brabantse kloostercomplexen. Masterscriptie in opdracht van de provincie Noord-Brabant.

[22] Farias, H. (2012), The design process in the rehabilitation of Portuguese historical monasteries: three case studies of the pousadas program. Paper presented at the IE International Conference 2012. Reinventing Architecture and Interiors: the past, the present and the future, Ravensbourne, U.K. 